\title{
A new method of gas drainage as a solution for dangerous phenomena in underground coal mines
}

The Mining-Geology-Petroleum Engineering Bulletin UDC: $622-2: 622.4$

DOI: 10.17794/rgn.2018.1.2

Review scientific paper

\author{
Pavel Zapletal'; Jaroslava Koudelková ; Václav Zubíček3; Tomáš Král'4; Andrea Mokrošová5 \\ ${ }^{1}$ VŠB-TU Ostrava, 17. listopadu 15/2172, 70833 Ostrava-Poruba, Associate Professor, doc.,Ing.,Ph.D. \\ ${ }^{2}$ VS̆B-TU Ostrava, 17. listopadu 15/2172, 70833 Ostrava-Poruba, Assistant Professor, Ing.,Ph.D \\ ${ }^{3}$ VŠB-TU Ostrava, 17. listopadu 15/2172, 70833 Ostrava-Poruba, Assistant Professor, Ing.,Ph.D \\ ${ }^{4} V \check{S} B-T U$ Ostrava, 17. listopadu 15/2172, 70833 Ostrava-Poruba, postgraduate student, Ing. \\ ${ }^{5}$ VŠB-TU Ostrava, 17. listopadu 15/2172, 70833 Ostrava-Poruba, postgraduate student, Ing.
}

\begin{abstract}
The further development of coal mining in different countries and in India is connected with many problems. The emission of gas, sudden outbursts of gas and coal, mine fires, dustiness, spontaneous combustion, methane concentration are very serious problems. This article deals with solving these problems. It describes a new method applied in coal mines in the Czech Republic that has brought very good results.
\end{abstract}

Keywords

Coal, methane, gas emission, dustiness, methane concentration.

\section{Introduction}

Problems that occur during coal mining in underground mines are solved differently in each country. Issues relating to the emissions of gases, sudden coal and gas outbursts in China namely (Hongpo et al., 1995)], fires, dustiness, spontaneous combustion and methane concentrations are important in countries with significant coal production (Singh, 2009; Prusty et al., 2010; Ghose, 2009; Hanes, 2006). It is necessary to assume that the coal mining will proceed in greater depths. (Singh et al., 2009).

The mining of coal at greater depths can cause complications, which can lead to increased gas content and a rise in temperature. The transition of mining works to greater depths has resulted in significant changes in the characteristics of rock mass and pressure conditions become more complicated. This paper summarizes the latest research and practical applications that have been achieved in this field in the Czech Republic.

The emphasis is put on the technique called a complex method of the methane degassing solution with the simultaneous watering of the coal bed. Using this method, we achieved a simultaneous reduction of the dustiness, the concentration of methane, and the danger of spontaneous combustion in all workplaces where it was used. This complex method has successfully been applied for many years and the results are very favourable.

Corresponding author: Pavel Zapletal

pavel.zapletal@vsb.cz

\section{Degassing of methane}

This method of the organized exhausting of gas was introduced in coal mines approximately in the middle of the 20th century. In the Czech Republic, we utilize it in all mines where mining results in the higher content of gas. For example, in mines in the Ostrava-Karvina basin (OKR), which have an annual output of $12 \mathrm{Mt}$ of coal, we lead away by drainage (degasification) 110 million cubic meters of $\mathrm{CH}_{4}$ per year from the total emission of 250 million cubic meters of $\mathrm{CH}_{4}$ per year.

Since (Bujok et al., 2015), the method of drainage (degasification) of gas called coal mining methane (CMM) is used in 14 countries of the world. In total, 3.8 billion of cubic meters of methane per year are conducted away by drainage. The common method of drainage is given in Figure 1.

Figure 1 shows that the boreholes are drilled in the surrounding rock behind the active coalface. This means that drainage only affects the caving area. The caving of the roof in this area means that along with methane, there are other gases (air) which can also flow in the boreholes, and this worsens the purity of methane. The purpose of the method we developed consists of situating the boreholes for methane drainage in advance of the coalface. An example of such a solution is shown in Figure 2.

The example of the new complex method is introduced from the coalface 065632 from Paskov colliery in the Czech Republic. It was known that drilling degasifi- 


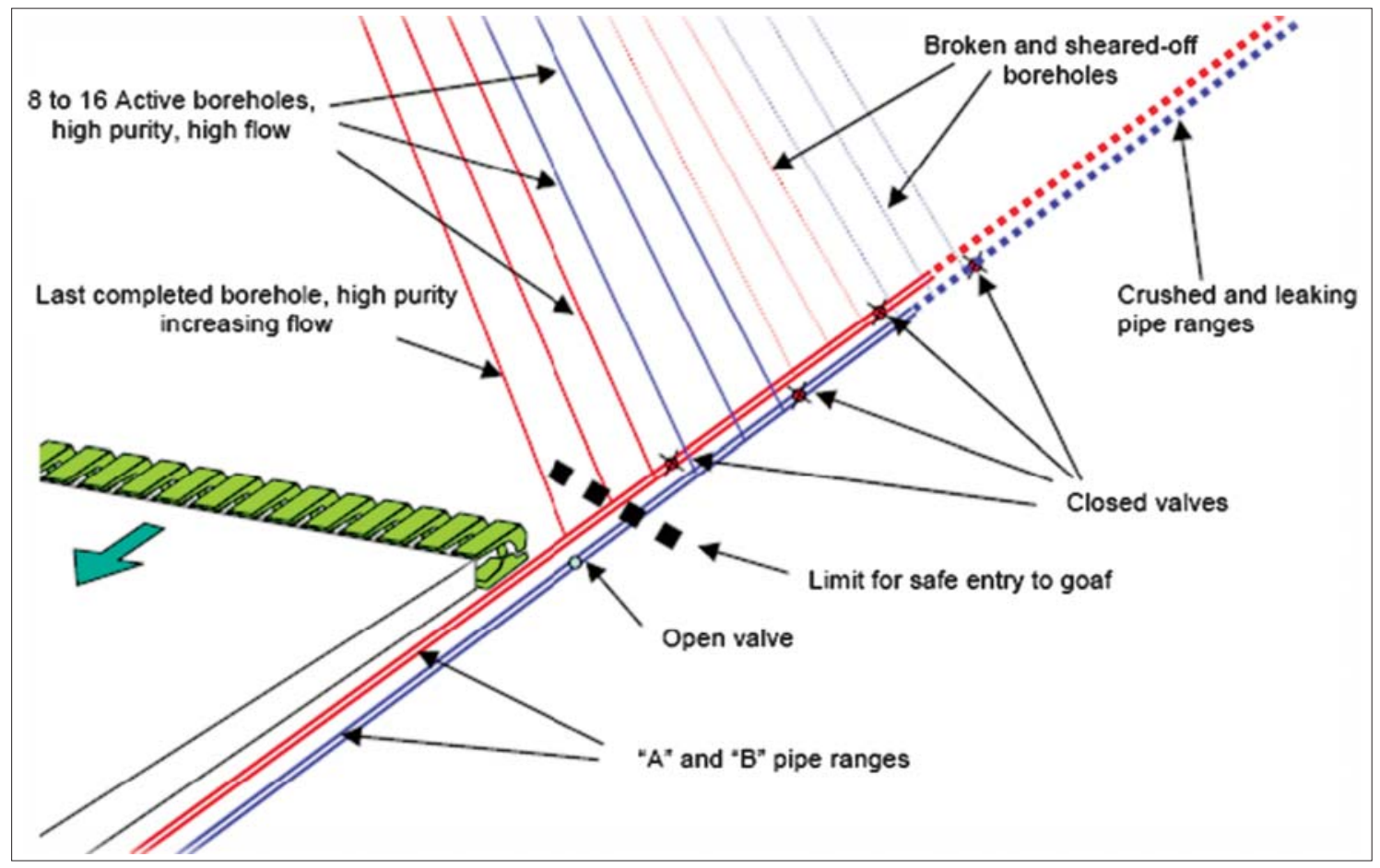

Figure 1: The common method of drainage methane from a coal seam (from Bujok et al., 2015)

cation boreholes in advance of the coalface was not very successful. The permeability of coal and the surrounding rock was very low and there was no gas circulation. However, we demonstrated that if boreholes in coal are drilled and irrigated simultaneously together with boreholes in the rock, permeability will be higher, which results in methane flowing. To achieve a positive effect, it is, however, necessary to respect the defined technological progress.

\section{Degasification system}

The difference in the degasification system using this new method compared to the common manner is that the boreholes for drainage are drilled at the front of the coalface, namely as far as to the extent of the entire block. The other parameters do not differ so much from the common version. The diameter of the pipeline is calculated using Equation (1).

$$
d=0,4788 \times\left(Q^{2} \times L \times \rho_{p} \times \Delta p^{-1}\right)^{0,2}
$$

Where:

$\mathrm{d}$ - pipeline diameter $(\mathrm{m})$

$\mathrm{Q}$ - quantity of gas flowed (cubic meters per second)

$\mathrm{L}$ - the length of the pipeline (m)

$\rho_{\mathrm{p}}$ - relative density (in relation to air) (1)

$\Delta p$ - pressure loss in the pipeline in the length $\mathrm{L}(\mathrm{Pa})$.

The pipeline should be dimensioned at a pressure of 0.6 MPa. We can see the degasification station in Figure 3.
Each pump has an operating capacity of 4,500 cubic meters per hour and under a pressure of $100 \mathrm{kPa}$. More information concerning the production of the entire system as well as the safety rules can be found in (Prokop, 2008; Prusty et al., 2010).

\section{Irrigation in long boreholes in advance of the coalface}

A very important measurement which can influence gas flow in drainage boreholes along with the dustiness and the danger of spontaneous combustion is the irrigation in long boreholes in advance of the coalface. It confirmed to us that for successful achievement of the desirable effect, some technical requirements have to be met. The necessary technical equipment which we use is:

- A drilling machine mostly TURMAG from Germany, or RVS-1, RVS-2 Czech production. See Figure 4.

- Spiral boring linkage largely flat linkage Cr 335 with a built-up spiral. See Figure 5.

- Boring crowns with a diameter of 42 or $65 \mathrm{~mm}$. See Figure 5.

- A pump, multiplier. See Figure 6.

- Packing of boreholes. Mechanical packing of long $1.5 \mathrm{~m}$ with rubber cuff, length $10 \mathrm{~cm}$. See Figure 7.

For irrigation, the pump multiplier which has a pressure of $20 \mathrm{MPa}$ showed good results. The intermittent pulsating movement of the piston in the pump allows for a gradual flooding of water to the pillar. It provides the possibility for the coal mass to absorb the water and dis- 


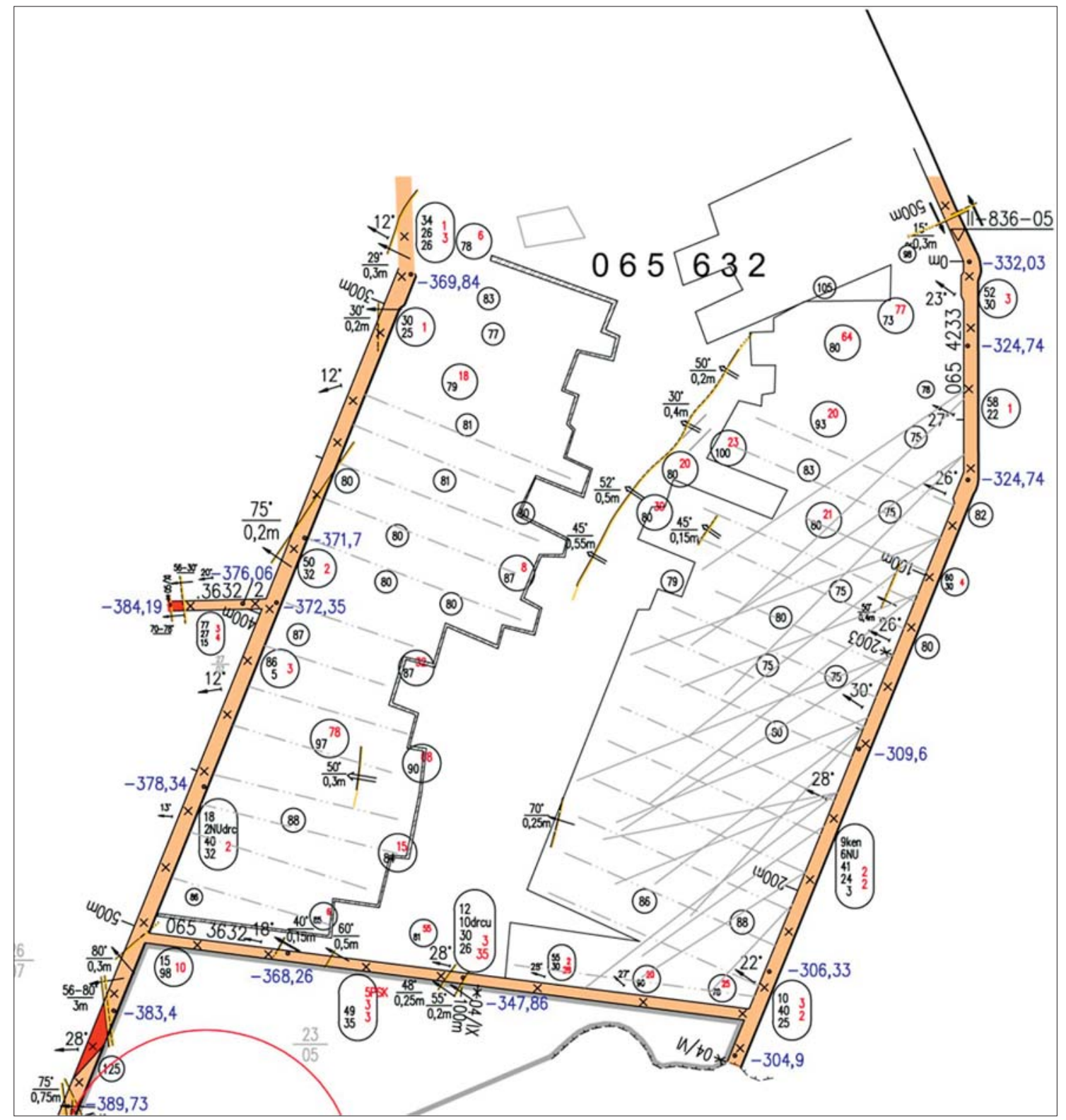

Figure 2: The example of the new complex method (from internal documents mine Paskov)

tribute it evenly. With rotary pumps, the coal mass was often disrupted, water escaped along the formed cracks and the desired effect was not achieved (Malvić et al., 2014). A perfect seal of the boreholes is very important, which is relatively reliable thanks to new agents (see Figure 7).

"Softening water" (decreasing the surface tension) from the central dosage soaking agent proved to be a very suitable arrangement that contributes to an improvement in the efficiency of irrigation. Hard water has a surface tension of 72 dynes per square $\mathrm{cm}$. This value was cut in half by the soaking agent. This modified water also deluges coal dust better.

It was shown that water forced into coal penetrates to contact elements in coal, thus among other things decreasing the strength of the coaly mass. It also affects the

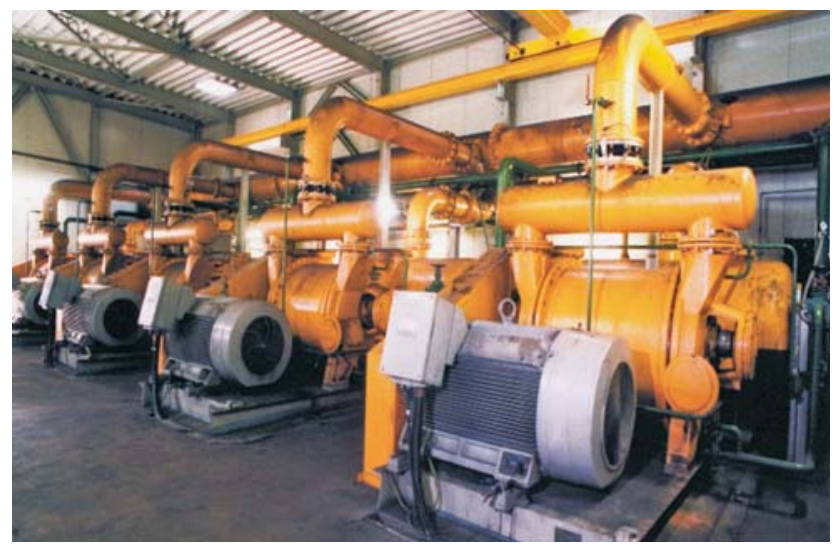

Figure 3: Degasification station. 5 units of water circle vacuum gas stations 


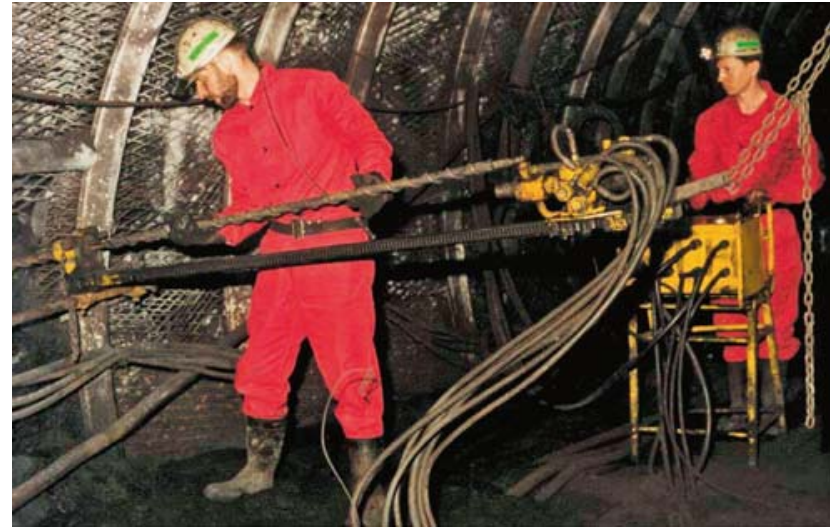

Figure 4: Drilling machine RVS-2
The quantity of water should be calculated before the irrigation is measured during the process. Irrigation must be carried out $30 \mathrm{~m}$ before the coalface in the area outside the influence of bottom pressure. The results of efficiency of the new complex method are shown in Table 1.

Relative exhalation is 102.5 cubic meters of methane per ton and this is really a very high value. However, $58 \%$ of the exhalation was conducted away by the drainage system, thus allowing for continuous mining. The drainage system in the zone before the coalface, 9000 cubic meters of methane was conducted per day. During the mining of this coalface and also the other coalfaces where the method was used did not result in dangerous methane concentration in the ventilation flow.

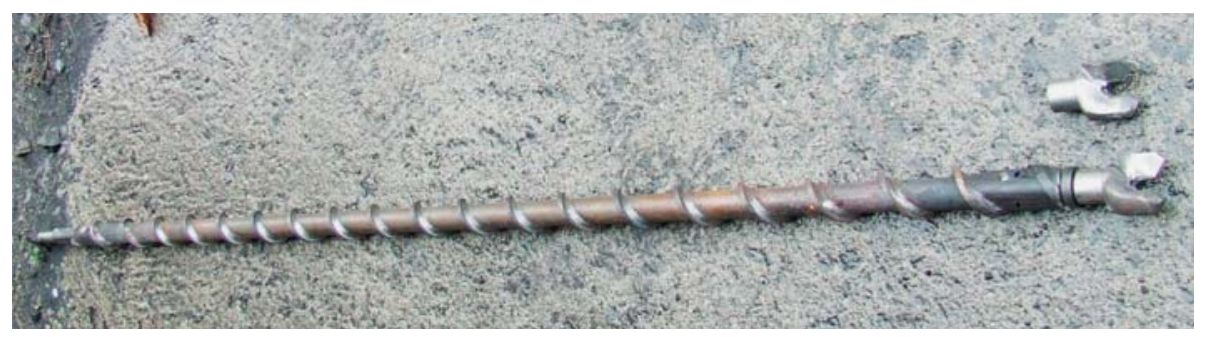

Figure 5: Spiral boring linkage and boring crowns diameter of $42 \mathrm{~mm}$

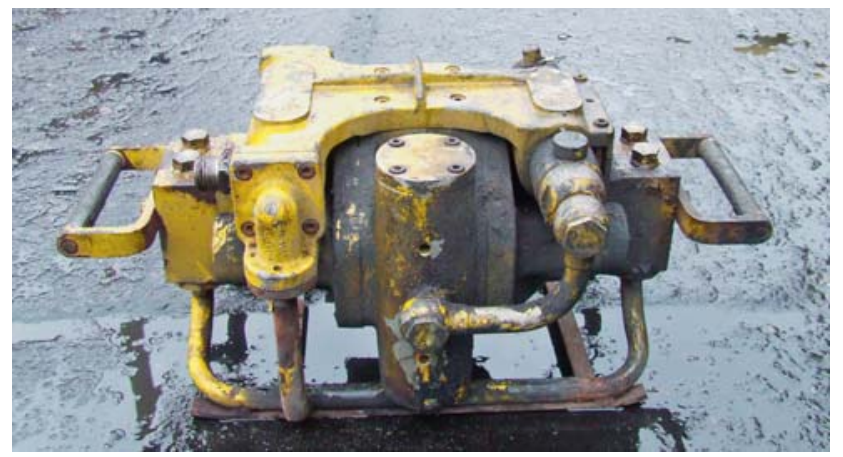

Figure 6: Pump, multiplier

country rock, especially the overburden, and results in releasing the gas from the coal seam and its surroundings. The degasification system is active at the same time as the irrigation, therefore the gas is driven in advance of the coalface. This eliminates hazard of outbursts of gas and coal and at the same time it lowers emissions while mining in the coalface.

The quantity of water for this system is $8-10$ litres per cubic meter of the coal mass. The coal mass is calculated as a diameter of the effective radius times the thickness of coal seam and length of the borehole. The effective radius around the borehole diameter with a diameter of $42 \mathrm{~mm}$ is $4-5 \mathrm{~m}$. For example, if the thickness of a coal seam is $1.2 \mathrm{~m}$, the length of the borehole is $60 \mathrm{~m}$, and the quantity of water needed for 1 borehole is:

$$
Q_{w}=5 \times 1,2 \times 60 \times 10=3600 l
$$

Where:

$\mathrm{Q}_{\mathrm{w}}$-quantity of water for 1 defined borehole.
The described procedure also significantly contributed to the improvement of environmental quality. (Santosh et al., 2009). Large amounts of gases, namely $\mathrm{CH}_{4}$ were conducted in the drainage pipeline, which limited its exit through the ventilation shaft.

\section{The influence of the new complex method on dustiness}

Very favourable results by using the method of irrigation in long boreholes were achieved in the decrease of dustiness. In coalfaces which were irrigated by conventional methods from the line of the coalface the dustiness was approximately 5.06 cubic milligrams per cubic meter of air. In coalfaces where the method of irrigation from the tail and main gates were used, the dustiness dropped to $2.59-2.61$ cubic milligram per cubic meter of air. From Figure 2, it is clear that owing to the irregular bedding of seam, the long boreholes cannot achieve such length to affect the whole length of the coalface front. The unaffected section then must be irrigated by short boreholes using the traditional method from the working part of the coalface. The section which must be irrigated by short boreholes should be as small as soon as possible. Irrigation in the zone of bottom pressure before the coalface is not very efficient.

\section{The influence of the new complex method on the spontaneous combustion of coal}

Spontaneous combustion of coal is a hazard frequently encountered in coal mining. It is researched exten- 
Figure 7: Packing of boreholes

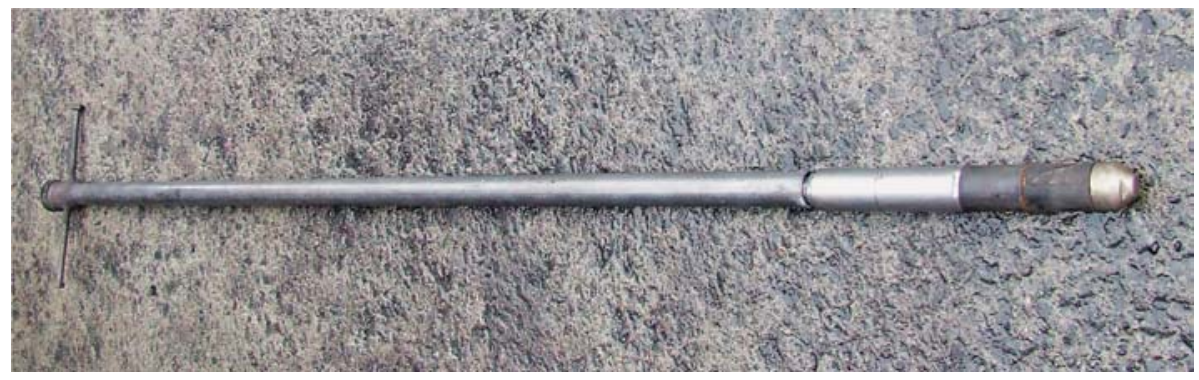

Table 1: The efficiency of the new complex method achieved in the coalface 065632 (see Figure 2).

\begin{tabular}{|l|c|c|c|c|c|}
\hline Period year & $\begin{array}{c}\text { Average } \\
\text { production ton per } \\
\text { day }\end{array}$ & $\begin{array}{c}\text { Exhalation cub. } \\
\text { meter methane per } \\
\text { day }\end{array}$ & $\begin{array}{c}\text { Degasification } \\
\text { cub. meter } \\
\text { methane per day }\end{array}$ & $\begin{array}{c}\text { Total emission cub. meter } \\
\text { methane per day }\end{array}$ & $\begin{array}{c}\text { Efficiency of } \\
\text { degasification (\%) }\end{array}$ \\
\hline 2006 & 302 & 12917 & 18055 & 30972 & 58,29 \\
\hline
\end{tabular}

sively but the actual mechanism by which it occurs is not completely understood. In underground mines, the most difficult situation occurs when spontaneous combustion takes place in the presence of an inherently explosive atmosphere.

After (Singh, 2009), in India there were around 66 active fires that had been identified within a 15-year time period. The project for the solution of this situation covered the identification of fire areas and a selection of technologies for dealing with fires and the prioritization of actions. Significant research was being conducted worldwide to develop methods for the early detection of heating through the monitoring of combustive products and the major gaseous products resulting from low temperature oxidation of coal, including $\mathrm{CO}_{2}, \mathrm{CO}$, and water vapour. The significant result of the existing research efforts were to reduce the risk of mine fires through the development of new or improved strategies and technologies for mine fire prevention, detection, control.

In this paper, we would like prove the dependence between the content of water in coal and its susceptibility to spontaneously combust. For this objective, we will use the results from the Ostrava-Karvina basin in the Czech Republic. Coal from this basin has a water content

$\mathrm{Wr}=0.8-4 \%$ in the Ostrava part and

$\mathrm{Wr}=0.8-0.6 \%$ in the Karvina part.

In the Karvina part of the basin, the susceptibility to spontaneously combust is far higher compared to the Ostrava part. This could confirm theories that water plays a very important function in the prevention against spontaneous combustion. It is important to prevent the dehydration of coal masses.

It is also proven, that a loss of moisture of a coal mass under the explicit limit and recovering moisture is dangerous as well. This can increase the risk of spontaneous combustion. For determining the susceptibility of coal to spontaneously combust, these methods are used:
- Adiabatic oxidation

- Method of Olpinski

- Pulsing calorimetry

- CPT Crossing Point temperature

- Isothermal sorption of oxygen.

With respect to determining the susceptibility of coal to spontaneously combust, we will present the results of the modified adiabatic method as it was developed at Technical University Ostrava in the Czech Republic and 35 coal samples were analysed (Zubíček, 2010). The conventional adiabatic method was based on analysis with an initial temperature of 40 or $800 \mathrm{C}$ till now. The Modified method is based on an increase of the initial temperature to $1200 \mathrm{C}$ with a laboratory test for the period of $60 \mathrm{~min}$.

Figures 8-9 show some results of the samples which indicate the possibility of a favourable influence of moisture to the susceptibility of spontaneous combustion. The samples are from one mine in the Karvina basin in the Czech Republic.

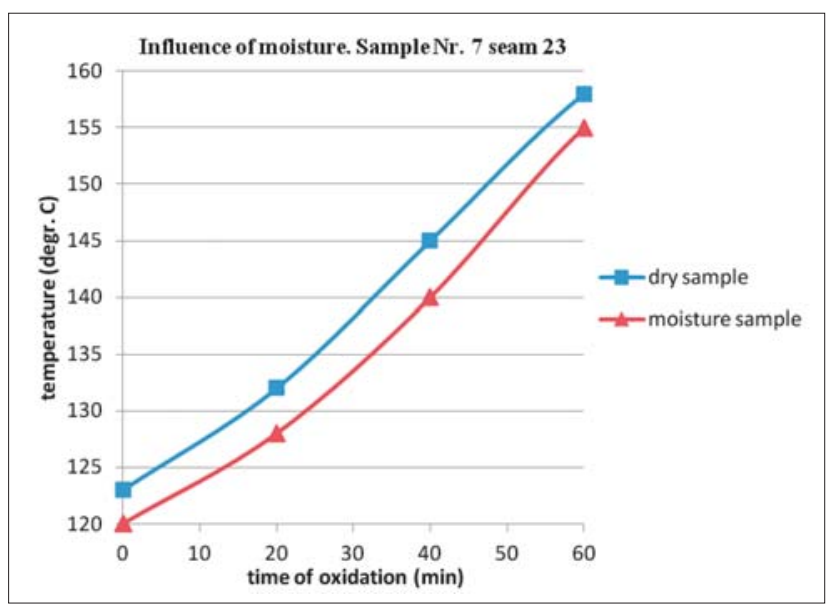

Figure 8: Increase of temperature of coal sample seam 23 (from Zubíček, 2010) 


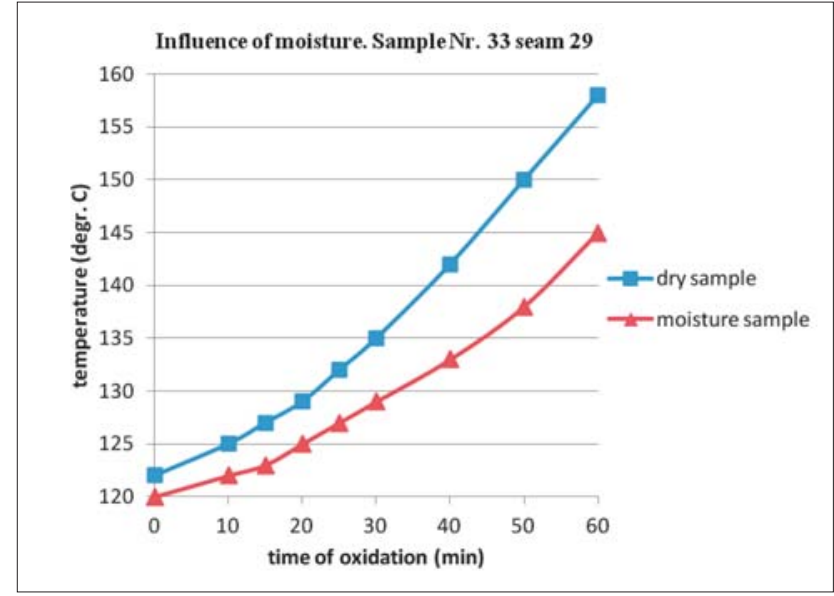

Figure 9: Increase of temperature of coal sample seam 33 (from Zubíček, 2010)

Figure 8 and Figure 9 demonstrate that the moisture of coal has an influence on the increase of temperature. At the end of testing, the final temperature for the dry sample no. 7 was higher by 3 degrees $C$ compared to the moist sample. With the dry sample no. 33, it was even 13 degrees $\mathrm{C}$ higher compared to the moist sample. This means that irrigation by the advance as it was described in this paper has a favourable influence on the emergence of spontaneous combustion.

\section{Conclusion}

The paper presents some theoretical and practical knowledge which can help reduce the influence of dangerous phenomena which originate in underground coal mines. By the new method of drainage of gas, it is possible to favourably affect the high emission of gas, dustiness, spontaneous combustion, and the concentration of gas in the work place. The method is based on the drainage of gas which is performed together with irrigation in long boreholes in advance before mining. The application of this method in the period of two decades in mines in the Czech Republic brought a substantial increase in productivity and work safety. The paper described how to manage the method and introduced figures and a description of the technical equipment. We are sure that after its application, this method will have positive results in every work place.

\section{References}

Bujok, P., Klempa, M., Slivka, V., Porzer, M., Němec, I., Št’astná, V., Smejkalová, E., Zdvořák, J. (2015): Remediation of the old ecological load in the protected area of the morava river - Re-abandonment of the oil and gas production wells. Rudarsko-geološko-naftni zbornik, 30, 1-8.

Ghose, A.K. (2009): Coal mine fires in India-an overview. Journal of Mines, Metals and Fuels Issue 11.

Hanes, J.(2006): Scoping study outburst management in Australia. Outburst Scoping study.

Hongpo, C., Yonxiang, L.(1995): Study and control of coal gas out outbourst In Didao coal mine in Chine. ymp.cum Warschow and Management \& Control of High Gas Emission \& Outbursts. Wollongong,NSW Australia.

Malvić, T., Rajić, R., Slavinić, P., Zelenika, K.N.(2014): Numerical integration in volume calculation of irregular anticlines. Rudarsko-geološko-naftni zbornik, 29, 1-8.

Prokop, P. (2008): Důlní degazace (Exhalation and drainage of gas). Textbook. Technical University Ostrava CR. (in Czech)

Prusty, B.K., Harpalani, S. (2010): Utilization of ventilation air methane - Feasibility study at Moonidih mine. Journal of Mines, Metals and Fuels, Issue 6, 141-146.

Santosh, K.R., Aditya, K.P., Sneha, R., Ghosh, A.K. (2009): Clean coal technology to improve environmental quality and energy efficiency Journal of Mines, Metals and Fuels, Mining Industry Annual Review 2009, September 2009, 267-274.

Singh, A.K. (2009): Coal exploration - Expanded requirement in India. Journal of Mines, Metals and Fuels, 57, 1-2.

Singh, A.K., Singh, R., Mandal, P.K., Kumar, R., Singh, A.K., Ram, S. (2009): Rock mechanics challenges of depillaring at deep cover. Journal of Mines, Metals and Fuels, 57, 9, 298-306.

Zubíček, V. (2010): Modifikace adiabatické metody ověřování náchylnosti uhlí $\mathrm{k}$ samovznícení pro podmínky OKR ( Modification of adiabatic method for verification of susceptibility of coal to spontaneous combustion). Dissertation work. Technical University Ostrava CR. (in Czech)

\section{Acknowledgements}

This paper was compiled within the Project of Specific University Research (SGS) no. SP2017/5 Methodological guide for determining optimal ventilation parameters for tunneling. The authors would like to thank the Faculty of Mining and Geology of VŠB - Technical University of Ostrava for the project support. 


\section{SAŽETAK}

\section{Nova metoda pridobivanja plina kao način smanjivanja opasnosti u podzemnim rudnicima ugljena}

Napredak u pridobivanju ugljena u mnogim je zemljama, posebice u Indiji, suočen s brojnim problemima. Postoje velike emisije plinova, njihove iznenadne eksplozije, požari, prašina, samozapaljenje te visoke koncentracije metana. U radu je opisano kako smanjiti ili ukloniti takve probleme, a prikazana je i nova metoda, već primijenjena u češkim rudnicima ugljena, koja je pokazala vrlo dobre rezultate.

\section{Ključne riječi}

ugljen, metan, emisija plina, prašina, koncentracija metana

\section{Authors contribution}

Pavel Zapletal, Jaroslava Koudelková - the initial idea for the article, research, concept development, wrote an article. Tomáš Král', Andrea Mokrošová - preparation and creation of the figures, correction the article by „authors instructions“. Václav Zubíček - research, cooperation with the influence of the new complex method on the spontaneous combustion of coal. 